\title{
21. ラットの先天性白内噇のリンケージテスト
}

\author{
村田 喜 宣 渡 辺智正東海林 隆次郎 \\ 愛知県心身障害者コロニー発達障害研究所
}

CWS/Idr 系ラットは, 遺伝性白内障のモデル動物 として近交育成された.これは $\mathrm{JcL}: \mathrm{SD}$ 系ラットに 自然発生した白内障形質を WKAH/Idr 系ラットと交 雑後, 選抜近交交配により分離固定したミュータント 系である. この形質は常染色体性単純劣性遺伝する が, 白内障, 小眼球症および虹彩後癒着を併発するこ とから遺伝子名 cms (cataract, microphthalmia and posterior synechia）が与えられた ${ }^{1)}$. 本研究ではこの $c m s$ 遺层子のリンヶージテストを試みた.

白内障と毛色または白斑遺伝子との連関を調査する ため, CWS/Idr 系 (cms/cms, $A / A, B / B, c / c, h / h)$ と $\mathrm{BN} / \mathrm{fMai}$ 系 $\left(+/+, a / a, b / b, C / C, h^{i} / h^{i}\right)$ を交 雑した. その結果 $F_{2}$ で出生仔 135 頭が得られ, 2 力 月齡で毛色, 白斑, および白内障の発症を観察した. 白内障については散瞳剤を点眼後スリットランプで発 症の有無を調べた. 135 頭のうち有色が 100 頭, アル ビノが 35 頭であり, 白内障が観察された個体は，そ れぞれ 12 頭, 18 頭であった. これは $c$ および $\mathrm{cms}$ 遣伝子が独立して遺伝するものと仮定した期待値との 間に有意な差（ $p<0.05, \chi^{2}$ 検定）があり，同一染色 体上に存在することが示唆された. また他の毛色遺伝 子または白斑遗伝子との連関は認められなかった。

ラットでは $c$ 遗伝子および $H b b$ 遺伝子は第一染色 体上で連関していることが知られているので2), これ らを標識として三点交雑を行った． $F_{1}$ をWS 系に戻 し交雑して得られた出生仔を材料とした. $H b b$ 遺伝子 については赤血球を 2 倍の $1 \mathrm{mM}-\mathrm{mDTA}$ 水溶液で溶 解し, セルロースフセテート膜 (Titan III) 上でTEB
(0.09 $\mathrm{M}$ Tris, $0.0016 \mathrm{~m}$ EDTA-Na 2, 0.05 м Boric acid）緩衝液を用いて電気泳動を行った. 泳動後, 膜 をポンソー $3 \mathrm{R}$ で 1 分間染色して $10 \%$ 酢酸で脱色し た. CWS 系は $H b b^{b} / H b b^{b}, \mathrm{BN}$ 系では $\mathrm{Hbba} / \mathrm{Hbba}$ であった. 戻し交雑によって得られた 113 頭のうち各 遺伝子間で組換えを示した個体は， $c$ と $H b b$ では 9 頭 (組換え率 7.9\%)，c と cms では 29 頭 (25.7\%), $\mathrm{Hbb}$ と cms では 33 頭 (29.2\%) であった. これれら の結果から cms 遺伝子は $c$ および $H b b$ の両遺伝子 と同一染色上にあり, $c$ 遺伝子から $22 \mathrm{cM}$ の位固にあ る Tam-1 遺伝子の近位に存在することが明らかとな ったが，Tam-1 遺伝子は CWS 系および BN 系にお いてタンパク変異では同型であり本実験では識別が不 可能であった. マウスでは $c, H b b$ ，および Tam-1 遺 伝子は第 7 染色体上に存在する. さらに Tam-1 遺伝 子の近位に Saa-1, Ldh-1 などいくつかの遺伝子が存 在することが明らかとなっている3). 現在 $S a a-1^{4)}$ お よび $L d h-1^{5)}$ 遺伝子を含む cDNA クローンを入手し, DNA レベルでこれらの遺伝子と cms 遺伀子との関連 を追跡している.

文献

1) Shoji, R. et al. : Teratology, 19, 47 (1979)

2) Rat News Lett., 18, 8 (1987)

3) Mouse News Lett., 81, 15 (1988)

4) Taylor, B.A. and Rowe, L. : Mol. Gen. Genet., 195, 491 (1984)

5) Miles, M.F. et al. : J. Biol. Chem., 256, 12545 (1981) 